\title{
The Necessity and Perfect path of the Chinese State-run Pension \\ Institutions in PPP
}

\author{
Sun Hongyu \\ Huazhong University of Science and Technology,Wuhan,Hubei,430074
}

\begin{abstract}
Keywords: public pension institution, public-private partnership, realistic motives, perfect path
\end{abstract}
\begin{abstract}
The implementation of Chinese state-run pension institutions in PPP is conducive to compensating for the government subsidies,promoting the reform process of the state-run old care institutions and accelerating the transformation of government functions.At present,in the implementation process,corporategovernancestructure of public institutions are in an urgent need to be strengthened, institutional environment of the public-private partnership be perfected and the market transaction system of the public-private partnership be constructed.
\end{abstract}

\section{Introduction}

Public-private partnership(abbreviated as PPP) refers to a system arrangement in which public departments and private departments establish the cooperative partnership and provide public products or services in a jointmanner. Originating from 1970s,PPP,as the core principle of the global governance transition, proposes that the private departments be introduced into the public service supplying sector,market system under which the multi-supplying structure be formed and the financial pressure be alleviated,the supply level and supply efficiency be enhances and the everincreasing demand for the public service be satisfied.Since the 21st century, PPP has spreaded around the globe and has become a core concept and a vital measure for governments of different countries to achieve the economic targets and enhance the public service standard.Public pension institution as a carrier for the government-investing old care service bears the social responsibility for helping the old in danger and is the last defense of China's social welfare system for the old.In recent years,with the ever-growing aging population,traditional old care service carriers are faced with doubts from different sectors.It has been a major task for us to consider how to realize the public pension institution reform and to improve the pension service supplying system.

In 2013,the State Council released Several Suggestions on Accelerating the Development of Pension Services(No.35 Document of State Council),Ministry of Civil Affairs released Notice on Carrying out Pilot Reform of Public Pension (No.369 Document of Ministry of Civil Affairs).In 2015,the Ministry of Civil Affairs and State Development and Reform Commission altogether ten departments jointly released Suggestions on Encouraging Private Capital to Participate in the Implementation of the Development of Pension Services(No.33 Document of Ministry of Civil Affairs) which aimed at encouraging private capital into public pension institutions and establishing the supply form of PPP in public pension.

In real practice,since 2013,nationwide,continuous efforts have been made on pilot reform of public pension institutions in PPP.By August 2016,the number of public pension institutions implementing state-found-private-ran in pilot project has amounted to over 1100.The PPP in this regard is making the transition from the experimental zone to the deep-water zone.Therefore,the necessity and perfect path of exploring the China's public pension institutions in PPP has become especially 
urgent.

\section{The necessity of the implementation of China's public pension institution in PPP}

Industrialization and moderation have brought the rapid development of human being which left behind the disabled,the old and the unemployed.Meanwhile,with the economic development,the population aging has created a strong demand for social expenditure.In China,with the evergrowing aging population,the demand for the institutional care skyrocketed and there is a need for the government to invest a large sum of money.According to statistics, from the perspective of central social welfare lotteries to civil affairs,expenditures on social welfare institutions have been on the rise(Table1).It is obvious that the demand for old care service can not be met merely with the government subsidies.PPP is introduced into the public old pension institutions via the private investment which eases the monetary pressure of the government.

Table1.Payment Table for the Public Welfare Fund to the Old Welfare (2010-2014)

Unit:10,000yuan

\begin{tabular}{|c|c|c|c|}
\hline Annual & $\begin{array}{c}\text { Projects for the Old } \\
\text { Social Welfare }\end{array}$ & $\begin{array}{c}\text { Institutions of the } \\
\text { Old Social Welfare }\end{array}$ & $\begin{array}{c}\text { Welfare on Public Fund } \\
\text { Expenditure }\end{array}$ \\
\hline 2010 & 60400 & 40630 & 57.36 \\
\hline 2011 & 85804 & 55674 & 60.00 \\
\hline 2012 & 110345 & 88345 & 54.88 \\
\hline 2013 & 127944 & 84644 & 89.46 \\
\hline 2014 & 110300 & 104000 & 49.05 \\
\hline
\end{tabular}

Data Source:Website of the Ministry of Civil Affairs:Notice on Use of the public welfare fund from the lottery at the corresponding level of the Year 2010,2011,2012,2013,2014

China's public pension system belongs to public undertaking department of Ministry of Civil Affairs and there exist some problems including rigid management system and sealed operation system.PPP as an innovative measures in the old age service supply sector will form an inducible revolution direction in the public old pension system and promotes the reform process in this regard.On one hand,PPP in the public pension system is beneficial for solving the political management method,introducing the modern management concepts and technique,bringing into full play of the management advantages of enterprises, promoting the current management method of the public pension institutions and enhancing theallocative efficiency of the public pension resources.On the other hand,the essence of PPP is that private capital is introduced into the public sectors and the nature of the private capital-profit pursuit will make the organization more sensitive to the market,provide the targeted old care service and satisfy the multiple demands of the old and enhance the pertinence and efficiency of the service provided by public pension institutions.

The implementation of the public pension institutions in PPP promotes the transition of the service function of the government.First,the public pension institutions in PPP realize the separation of management office of public pension institutions, help government get rid of detail affairs,avoid the overstaffed institutions institutions, alleviate the pressure from the professional resources and enhance the resources availability factor.Second,the implementation of the public pension 
institutions in PPP facilitate the transition of the government role from the welfare state to the opportunity company,expand the public participating channel,solve the general public affairs,provide a platform for the communication between different social sectors, strengthen the service function of the government.Finally,the PPP puts much emphasis on the positive interactions among plural subjects including government,market and society which clarifies the boundary between government and market,strengthens the legal awareness and contract awareness of the government, better fulfills the public function and enhances the service level of the government in a comprehensive manner.

\section{The perfect path of public pension institutions in PPP}

At present,the major problem of the public pension institutions in PPP is that the corporate governance is imperfect,the status of the legal person is not put into real practice,the combination of the politics with affairs which leads to unclear targets and the non-standard cooperation process.In the bidding and tendering process, the bidders are not unified.Some sectors participate in the bidding and tendering in the name of public pension institutions while some in the name of the civil affairs departments which may cause problems in the PPP implementation.Therefore,it is am important topic to speed up the reform process of the public institutions and perfect the corporate governance in China's public institutions.According to the exploration experience in the reform on public institutions,the core of the corporate governance is to divide the powers of decisionmaking,enforcement and supervision.Thus,the system management that three powers are appropriately separated and mutually inter-coordinated can be established.First,the council is established which exercises the decision-making power of the public institutions and meanwhile takes the responsibility for the overall supervision on the management in public institutions. Government delegates part of the bidding power and handling management power to the council which is responsible for setting up the development plan for public institutions. The structure of council members should be fully representative including the government,delegates from the government and also representatives of the service targets, professionals, representatives of employee and other stakeholders. Members of the council need to be the officially appointed.Second,the recruitment of professional management resources should be open to the society who exercise the specific management power and take the responsibility for daily management work. Executive members are determined by the council or nominated by the council and appointed by the responsible departments. Principal administrators are legal representatives of the public institutions and are responsible for the council.Third,the specialized supervision organization should be set up and the supervision on the internal management should be strengthened.Supervision institutions should be responsible for the government and the public and carry out the comprehensive supervision on management control in public institutions.

To improve the system environment lays a solid foundation for the sustainable development of China's public pension institutions in PPP.At present,in the implementation process, the key in system environment is to improving the legal and regulation system.There exist imperfection and even mutual contradiction in the current legal and regulation system which have resulted in the obstacles to the smooth development of PPP and in this sense,there is no rules to follow and no laws to abide by in the corporation process.For example,there is no detailed regulation standards for the selection of the corporation targets. However,according to Suggestions on Encouraging Private Capital to Participate in the Implementation of the Development of Pension Services(No.33 Document,Ministry of Civil Affairs), open tendering should be exercised.The Bidding Law emancipated in 1999 is the guiding law which should be based on engineering tendering and 
bidding.In the process,the qualification of bidders and projects operation are very complicated.However,other practices in China's public services,managers have explored some approaches to find appropriate partners including recruitment,competitive negotiation and direct entrust but a complete regulation and tendering degree has not yet been settled.In real practice,the selection of partners mail rely on experience and thus the transparency and irregularity would leave room for corruption. Therefore,to improve the corresponding laws and regulations will lay a solid legal foundation for the long-term development of China's pension institutions in PPP and secures the smooth implementation of the China's pension institutions in PPP.

\section{Improving the market system for PPP}

The essence of PPP is that the most professional and competent market players can have the access to the market system and the cooperative surplus can be achieved and therefore to improve the market system is a vital requirement of the PPP.First,the market access should be broader ,investment barriers in pensions institutions need to be phased out and various types of private investment encouraged to enter into public pension institutions.Thus,a multi-supplying investment structure should be established.Second,a fair environment needs to be fostered and the monopoly that the state-run enterprises control the market should be prevented.In the PPP formation stage,the market system is achieved via bidding and tendering.The essence is that the price competition and winners should reflect the overall performance including strength and reputation.Every bidder should be given the equal chance and private enterprises should be given the equal treatment.Bidders should be mutually independent and bid-rigging and collusive bidding should be prevented.Every bidder should be given the same project information and information should not be leaked in the process.Judging index and judging approach should be unified and the process should be open and transparent.As for the enterprises with the same qualification, private enterprises should be considered first.Finally,market order should be maintained.On one hand,interest of private sectors should not be harmed,especially the intrusion from the local interest group so that economic disputes can be avoided.On the other hand,people's interests should be secured and improper conduct should be regulated or punished.

\section{References}

[1]E.S Savas.Privatization and Public-Private Partnerships[M],Zhou Zhiren,translator,Beijing:China Renmin University Press Co.Ltd.

[2] Wilensky,H., The Welfare State and Equality:Structural and Ideological Roots of Public Expenditures[M],Berkelye,Calif:University of California press . 1975.

[3]Li Danyang.Public-private Partnership from the Perspective of Global Administrative Reform[J].SHZX Journal,2008(6) 